\title{
Penerapan Metode Tutor Sebaya Berbantuan Modul Pembelajaran Matematika Berbasis Keterampilan Literasi terhadap Hasil Belajar Matematika
}

\author{
Rizky Ramadhana \\ Pendidikan Matematika, STKIP YPUP Makassar \\ Email:rizkyramadhana53@gmail.com
}

\begin{abstract}
Article History:
Received: DD-MM-YYYY; Received in revised form: DD-MM-YYYY; Accepted: DD-MM-YYYY; Available online: DD-MM-YYYY
\end{abstract}

\begin{abstract}
This study aims to find out the mathematics learning outcomes of students after applying peer tutoring methods assisted by mathematics learning modules based on literacy skills and to find out the mathematics learning outcomes of students after applying peer tutoring methods assisted by mathematical learning modules based on literacy skills have reached a minimum standard. The type of this study is pre-experiment (Pre experimental design) with the research design used is the One-shot case study design, which was conducted at the MA Ihya 'Ulumiddin Kampung Beru with the research population being students of class XI 2016/2017 academic year and research samples this is the XIB class where class determination is done randomly. The results of the study show that the mathematics learning outcomes of the XIB MA Ihya Ulumiddin students taught by applying peer tutoring methods obtain an average score of 81.53 with a standard deviation of 7.76. If the score is adjusted to the minimum standard, it indicates that the minimum standard achieved is 75\% so that it can be stated that students who have reached a minimum standard of 12 students (80\%). Furthermore, in testing the hypothesis, the results obtained are HO rejected and H1 accepted, this indicates that the mathematics learning outcomes of students taught by applying the peer tutoring method have reached a minimum standard of $75 \%$.
\end{abstract}

Keywords: Peer Tutor Method; Mathematics Learning Module Based on Literacy Skills; Learning Outcomes.

\begin{abstract}
Abstrak
Penelitian ini bertujuan untuk mengetahui hasil belajar matematika peserta didik setelah diterapkan metode tutor sebaya berbantuan modul pembelajaran matematika berbasis keterampilan literasi dan untuk mengetahui hasil belajar matematika peserta didik setelah diterapkan metode tutor sebaya berbantuan modul pembelajaran matematika berbasis keterampilan literasi telah mencapai standar minimal. Adapun jenis penelitian ini adalah pre-Eksperimen (Pre experimental design) dengan desain penelitian yang digunakan adalah disain One-shot case study, yang dilaksanakan di MA Ihya' Ulumiddin Kampung Beru dengan populasi penelitiannya adalah peserta didik kelas XI tahun ajaran 2016/2017 dan sampel penelitian ini adalah kelas $X I_{B}$ dimana penentuan kelas dilakukan secara random. Hasil penelitian menunjukkan bahwa hasil belajar matematika peserta didik kelas XI $I_{B}$ MA Ihya Ulumiddin yang diajar dengan menerapkan metode tutor sebaya memperoleh skor rata-rata 81,53 dengan standar deviasi 7,76. Jika skor disesuaikan dengan standar minimal menunjukkan bahwa standar minimal yang dicapai yaitu $75 \%$ sehingga dapat dikemukakan
\end{abstract}


bahwa peserta didik yang telah mencapai standar minimal sebanyak 12 peserta didik (80\%). Selanjutnya pada pengujian hipotesis, hasil yang diperoleh adalah $H_{0}$ ditolak dan $H_{1}$ diterima, hal ini menunjukkan bahwa hasil belajar matematika peserta didik yang diajar dengan menerapkan metode tutor sebaya telah mencapai standar minimal yaitu $75 \%$.

Kata Kunci: Metode Tutor Sebaya; Modul Pembelajran Matematika Berbasis Keterampilan Literasi; Hasil Belajar.

\section{Pendahuluan}

Pendidikan bukanlah suatu hal yang statis, melainkan suatu hal yang dinamis sehingga menuntut adanya suatu perubahan atau perbaikan secara terus menerus. Perubahan dapat dilakukan dalam hal metode mengajar, buku-buku, alat-alat laboratorium, maupun materi-materi pelajaran.Salah satu bidang studi yang penting dalam pendidikan adalah matematika oleh karenanya matematika merupakan mata pelajaran yang diajarkan pada semua jenjang pendidikan.

Pembelajaran matematika sekolah tidak hanya berorientasi pada materi ajar, tetapi berorientasi pada peserta didik aktif baik fisik, mental maupun sosial dalam pembelajaran. Namun pada kenyataannya yang terjadi di lapangan bahwa pada proses pembelajaran yang aktif adalah guru atau dengan kata lain pembelajaran masih berpusat pada guru sehingga peserta didik hanya menjadi penerima informasi dan guru pemberi informasi sehingga proses pembelajaran bersifat pasif yang berdampak negatif bagi peserta didik salah satu diantaranya peserta didik pasif. Sikap pasif tersebut misalnya peserta didik enggan bertanya, waktu yang disediakan untuk bertanya jarang dipergunakan, serta diantara peserta didik jarang terjadi diskusi ataupun tanya jawab. Kenyataannya menunjukkan bahwa tidak banyak peserta didik yang mau dan suka bertanya kepada temannya untuk mengatasi kesulitannya, apalagi kepada guru. Selain itu, tidak jarang terjadi pada saat pembelajaran peserta didik belum mampu untuk merumuskan, menggunakan, dan menafsirkan matematika dalam berbagai konteks di kehidupan sehari-hari.Salah satu sekolah yang mengalami masalah tersebut adalah MA Ihya Ulumiddin.

Untuk mengatasi hal tersebut diperlukan kreativitas seorang guru dalam menggunakan metode mengajar yang bervariasi agar pembelajaran menjadi lebih bermakna.Belajar bukan hanya sekedar mendengar dan mencatat saja. Proses belajar memerlukan keterlibatan aktivitas jasmani dan rohani, fisik dan mental untuk bereksperimen atau demonstrasi sehingga meningkatkan partisipasi aktif peserta didik dan meningkatkan hasil belajar peserta didik. 
Salah satu metode yang berkembang saat ini adalah metode pembelajaran tutor sebaya. Dengan menerapkan tutor sebaya dalam kelompok kecil merupakan salah satu alternatif untuk membantu peserta didik mempermudah belajar matematika. Hal ini mungkin mengingat dalam satu kelas peserta didik mempunyai taraf kecerdasan yang heterogen, dimana terdapat peserta didik yang pandai, sedang dan kurang pandai.Peserta didik yang pandai itulah yang difungsikan sebagai tutor sebaya karena adakalanya seorang peserta didik lebih mudah menerima keterangan yang diberikan oleh teman-teman sebayanya sehingga dengan bantuan tutor sebaya ini diharapkan peserta didik benar-benar mengerti, dan pada akhirnya dapat meningkatkan prestasi para tutor dan para peserta didik yang ditutori.

Metode secara harfiah berarti cara. Dalam pemakaian yang umum metode diartikan sebagai suatu cara atau prosedur yang dipakai untuk mencapai tujuan tertentu. Metode mengajar adalah cara-cara menyajikan bahan pembelajaran kepada peserta didik untuk tercapainya tujuan yang telah ditetapkan ${ }^{1}$.

Tutor sebaya dikenal dengan pembelajaran teman sebaya atau antar peserta didik, hal ini bisa terjadi ketika peserta didik yang lebih mampu menyelesaikan pekerjaannya sendiri dan kemudian membantu peserta didik lain yang kurang mampu. Tutor sebaya merupakan salah satu metode pembelajaran untuk membantu memenuhi kebutuhan peserta didik. Dimana dalam pelaksanaannya tutor sebaya adalah peserta didik pembantu guru dalam dalam kegiatan belajar mengajar di kelas. Tutor sebaya adalah seorang atau beberapa orang peserta didik yang ditunjuk dan ditugaskan untuk membantu peserta didik lain yang mengalami kesulitan belajar. Tutor tersebut diambil dari kelompok peserta didik yang prestasinya lebih tinggi ${ }^{2}$.

Dalam pembelajaran tutor sebaya terdapat ciri-ciri yang menjadi kekhasan dari pembelajaran ini. Ciri-ciri itu antara lain sebagai berikut.

1. Tujuan pengajaran dari pembelajaran tutor sebaya ini adalah memberikan kesempatan kepada setiap peserta didik untuk mengembangkan kemampuan memecahkan masalah secara rasional, mengembangkan

1 Pupuh Fathurrohman and M. Sobry Sutikno, Strategi Belajar Mengajar Melalui Penanaman Konsep Umum dan Konsep Islami Edisi 1 (Refika Aditama, 2011), https://openlibrary.telkomuniversity.ac.id/pustaka/21504/strategi-belajar-mengajarmelalui-penanaman-konsep-umum-dan-konsep-islami-edisi-1.html.

2 Tim MKPBM Jurusan Pendidikan Matematika, "Strategi Pembelajaran Matematika Kontemporer" (JICA Universitas Pendidikan Indonesia, 2001), http://file.upi.edu/Direktori/KD-

TASIKMALAYA/DINDIN_ABDUL_MUIZ_LIDINILLAH_\%28KD-TASIKMALAYA\%29$197901132005011003 / 132313548 \% 20$ -

\%20dindin \%20abdul\%20muiz\%20lidinillah/Strategi\%20Pembelajaran\%20Matematika\%2 0\%28Lokakarya\%20Guru\%20SD\%20Kawalu\%29.pdf. 
sikap sosial dan semangat gotong royong dalam kehidupan, mendinamiskan kegiatan kelompok dalam belajar sehingga tiap anggota merasa diri sebagai bagian kelompok yang bertanggung jawab, mengembangkan kemampuan kepemimpinan ketrampilan pada tiap anggota kelompok dalam pemecahan masalah kelompok.

2. Peserta didik dalam pembelajaran ini memiliki ciri-ciri:

a. Tiap peserta didik merasa sadar diri sebagai anggota kelompok.

b. Tiap peserta didik merasa sadar diri memiliki tujuan bersama berupa tujuan kelompok.

c. Memiliki rasa saling membutuhkan dan tergantung.

d. Interaksi dan komunikasi antar anggota.

e. Ada tindakan bersama sebagai perwujudan tanggung jawab kelompok.

3. Peranan guru terdiri dari pembentukan kelompok, perencanaan tugas kelompok, pelaksanaan, dan tahap evaluasi hasil belajar kelompok.

Langkah-langkah pelaksanaan metode tutor sebaya adalah sebagai berikut berikut:

1. Tahap Persiapan

a. Guru membuat program pengajaran satu pokok bahawan yang dirancang dalam bentuk pokok bahasan

b. Menentukan beberapa orang asing yang memenuhi kriteria sebagai tutor sebaya.

c. Mengadakan latihan bagi tutor sebaya

d. Mengelompokkan siswa dalam kelompok yang beranggotakan 4-7 orang

2. Tahap Pelaksanaan

a. Guru memberikan pengatra terlebih dahulu tentang materi yang diajarkan

b. Siswa belajar mandir dalam kelompoknya sendiri, tutor mengatasi kesulitan yang ada dalam setiap kelompok. Apabila ada masalah yang tidak dapat diselesaikan barulah tutor meminta bantuan guru

c. Guru mengawasi jalannya kegiatan pembelajaran

3. Tahap Evaluasi

a. Guru memberikan soal latihan setelah kegiatan pembelajaran dilakukan

b. Mengingatkan tutor untuk mempelajarai sub pokok bahasa selanjutnya di rumah. ${ }^{3}$

Selain metode pembelajaran, kegiatan pembelajaran perlu dilengkapi dengan bahan ajar yang dapat menunjang proses belajar mengajar. Salah satu bahan ajar yang dapat dikembangkan adalah modul pembelajaran. Modul adalah bahan ajar yang dirancang secara sistematis berdasarkan kurikulum

\footnotetext{
${ }^{3}$ Oemar Hamalik, Proses Belajar Mengajar (Jakarta: Bumi Aksara, 2017).
} 
tertentu dan dikemas dalam bentuk satuan pembelajaran terkecil dan memungkinkan dipelajari secara mandiri dalam satuan waktu tertentu agar peserta didik menguasai kompetensi yang diajarkan4. Modul pembelajaran menurut Winkel, merupakan satuan program belajar mengajar yang terkecil, yang dipelajari oleh peserta didik sendiri secara perseorangan atau diajarkan oleh peserta didik kepada dirinya sendiri (self-instructional) ${ }^{5}$.

Modul adalah suatu cara pengorganisasian materi pelajaran yang memperhatikan fungsi pendidikan. Strategi pengorganisasian materi pembelajaran mengandung squencing yang mengacu pada pembuatan urutan penyajian materi pelajaran, dan synthesizing yang mengacu pada upaya untuk menunjukkan kepada pebelajar keterkaitan antara fakta, konsep, prosedur dan prinsip yang terkandung dalam materi pembelajaran ${ }^{6}$.

Berdasarkan beberapa pengertian modul tersebut maka dapat disimpulkan bahwa modul pembelajaran adalah salah satu bentuk bahan ajar yang dikemas secara sistematis dan menarik sehingga mudah untuk dipelajari secara mandiri.

Literasi matematika secara umum diartikan sebagai suatu kesatuan dari pengetahuan, pemahaman, dan keterampilan yang dibutuhkan manusia untuk berfungsi secara efektif dalam kehidupan modern.

Literasi matematika diartikan sebagai kemampuan seseorang untuk merumuskan, menerapkan dan menafsirkan matematika dalam berbagai konteks, termasuk kemampuan melakukan penalaran secara matematis dan menggunakan konsep, prosedur, dan fakta untuk menggambarkan, menjelaskan atau memperkirakan fenomena/kejadian.Literasi matematika membantu seseorang untuk memahami peran atau kegunaan matematika di dalam kehidupan sehari-hari sekaligus menggunakannya untuk membuat keputusan-keputusan yang tepat sebagai warga negara yang membangun, peduli dan berpikir7.

Dalam PISA 2012 menyebutkan literasi matematika melibatkan 7 kemampuan dasar yang harus dimiliki, yaitu:

2. Communication, kemampuan untuk mengomunikasikan masalah. Dalam hal ini bahwa seorang peserta didik melihat adanya suatu masalah dan kemudian tertantang untuk mengenali dan memahami permasalahan tersebut.Membuat model merupakan langkah yang sangat penting untuk memahami, memperjelas, dan merumuskan suatu masalah. Dalam proses

\footnotetext{
4 Darmiatun, Menyusun Modul Bahan Ajar Untuk Persiapan Guru Dalam Mengajar (Yogyakarta: Gava Media, 2013).

5 Winkel, Psikologi Pengajaran (Yogyakarta: Media Abadi, 2009).

${ }^{6}$ Indrayanti, Norma Y, and Endang Susilowati, Pengembangan Modul (Surakarta: Tim Pengabdian Kepada Masyarakat LPPM UNS, 2010).

${ }^{7}$ Sri Wadhani and Rumiati, Instrumen Penilaian Hasil Belajar Matematika SMP Belajar Dari PISA Dan TIMSS (Yogyakarta: PPPPTK-Kemendikbud, 2011).
} 
menemukan penyelesaian, hasil sementara mungkin perlu dirangkum dan disajikan. Selanjutnya, ketika penyelesaian ditemukan, hasil juga perlu disajikan kepada orang lain disertai penjelasan serta justifikasi. Kemampuan komunikasi diperlukan untuk bisa menyajikan hasil penyelesaian masalah.

3. Mathematising, kemampuan untuk mengubah permasalahan dari dunia nyata ke bentuk matematika ataupun sebaliknya. Literasi matematika juga melibatkan kemampuan untuk mengubah (transform) permasalahan dari dunia nyata ke bentuk matematika atau justru sebaliknya yaitu menafsirkan suatu hasil atau model matematika ke dalam permasalahan aslinya.

4. Representation, kemampuan untuk menyajikan kembali suatu permasalahan matematika. Literasi matematika melibatkan kemampuan untuk menyajikan kembali (representasi) suatu permasalahan atau suatu obyek matematika melalui hal-hal seperti: memilih, menafsirkan, menerjemahkan, dan mempergunakan grafik, tabel, gambar, diagram, rumus, persamaan, maupun benda konkret untuk memotret permasalahan sehingga lebih jelas

5. Reasoning and Argument, kemampuan menalar dan memberi alasan. Kemampuan ini berakar pada kemampuan berpikir secara logis untuk melakukan analisis terhadap informasi untuk menghasilkan kesimpulan yang beralasan.

6. Devising Strategies for Solving Problems, kemampuan menggunakan strategi memecahkan masalah. Beberapa masalah mungkin sederhana dan strategi pemecahannya terlihat jelas, namun ada juga masalah yang perlu strategi pemecahan cukup rumit.

7. Using Symbolic, Formal and Technical Language and Operation, kemampuan menggunaan bahasa simbol, bahasa formal dan bahasa teknis.

8. Using Mathematics Tools, kemampuan menggunakan alat-alat matematika, misalnya dalam pengukuran ${ }^{8}$.

Beberapa penelitian tentang penerapan metode tutor sebaya menunjukkan hasil yang positif terhadap hasil beljaar. Beberapa diantaranya seperti yang dikemukakan oleh Muhammad Fauzan dkk yang menyatakan bahwa penerapan metode tutor sebaya dapat meningkatkan ketuntasan klasikal pada mata pelajaran Statistika9. Metode tutor sebaya juga dapat

8 OECD, "Pisa 2012 Assessment and Analytical Framework Mathematics, Reading, Science, Problem Solving and Financial Literacy" (OECD Publishing, 2013), https://www.oecd.org/pisa/pisaproducts/PISA\%202012\%20framework\%20ebook_final.pdf.

9 Muhammad Fauzan, Noor Taufiq Saleh, and Ardhi Prabowo, "Penerapan Pembelajaran Model PBL Dengan Metode Tutor Sebaya Pada Materi Statistika Untuk 
mengatasi kesulitan belajar siswa sebagaimana dikemukakan oleh Anita dkk 10. Berdasarkan hal tersebut, maka penelitian ini mencoba untuk mengetahui hasil belajar matematika peserta didik setelah diterapkan metode tutor sebaya berbantuan modul pembelajaran matematika berbasis keterampilan literasi.

\section{Metode}

Penelitian ini termasuk kategori pre-Eksperimen (Pre experimental design) dengan desain penelitian yang digunakan adalah disain Oneshotcasestudy dengan diagram

$$
\text { X ------- } 0
$$

Keterangan :

$\mathrm{O}=$ observasi yang dilakukan sesudah perlakuan (post test)

$\mathrm{X}=$ perlakuan kepada peserta didik yaitu pengajaran dengan metode tutor sebaya.

Penelitian ini dilaksanakan di MA Ihya Ulumiddin Kampung Beru Kabupaten Bantaeng. Populasi dalam penelitian ini peserta didik kelas XI MA Ihya Ulumiddin Kampung Beru tahun pelajaran 2016/2017 dengan sampel penelitian ini adalah kelas $\mathrm{XI}_{\mathrm{B}}$ dimana penentuan sampel dilakukan secara random.

Sebelum melaksanakan penelitian maka terlebih dahulu dilakukan perencanaan agar penelitian berjalan dengan lancar. Hal yang dilakukan adalah: (1) menelaah kurikulum untuk bidang studi matematika, (2) mempersiapkan perangkat pembelajaran berupa rencana pembelajaran, modul, lembar kerja peserta didik, (3) mempersiapkan tes hasil belajar matematika. Pelaksanaan penelitian dilakukan dengan menerapkan metode tutor sebaya pada kelas eksperimen yang terpilih yaitu kelas $\mathrm{XI}_{\mathrm{B}}$. Instrumen yang digunakan untuk mengumpulkan data yaitu tes hasil belajar matematika.Bentuk tes yang digunakan yaitu tes uraian.

Data yang telah terkumpul dari kelas sampel selanjutnya dianalisis dengan menggunakan teknik statistik deskriptif dan statistik inferensial.Analisis deskriptif ini digunakan untuk mendeskripsikan skor hasil belajar matematika kelas $\mathrm{XI}_{\mathrm{B}}$ MA Ihya Ulumiddin Kampung Beru yang diajar dengan menerapkan metode tutor sebaya berbantuan modul pembelajaran matematika berbasis keterampilan literasi. Sedangkan analisis inferensial digunakan untuk menguji hipotesis penelitian. Uji hipotesis

Meningkatkan Ketuntasan Klasikal Siswa Kelas XII MIPA 1 SMAN 9 Semarang Tahun Pelajaran 2018/2019," PRISMA, Prosiding Seminar Nasional Matematika 2 (February 13, 2019): 403-9.

10 Anita, Wahyudi, and Miliani, "Pengaruh Remedial Teaching Tutor Sebaya Dalam Mengatasi Kesulitan Belajar Siswa Pada Materi Hukum Newton Kelas X IPA SMA Negeri 1 Jongkong Kabupaten," 2017. 
statistik dilaksanakan untuk menjawab hipotesis penelitian. Sebelum uji hipotesis statistik maka terlebih dahulu dirumuskan hipotesis statistiknya. Hipotesis yang diajukan:

$\mathrm{H}_{0}=$ Hasil belajar matematika peserta didik setelah diterapkan metode tutor sebaya berbantuan modul pembelajaran matematika berbasis keterampilan literasi belum mencapai standar minimal

$\mathrm{H}_{1}=$ Hasil belajar matematika peserta didik setelah diterapkan metode tutor sebaya berbantuan modul pembelajaran matematika berbasis keterampilan literasi telah mencapai standar minimal.

Untuk menghitung t digunakan rumus sebagai berikut ${ }^{11}$ :

Keterangan:

$$
t=\frac{\bar{x}-\mu_{0}}{\frac{s}{\sqrt{n}}}
$$

$\bar{x}=$ skor rata-rata

$s=$ standar deviasi

$\mu_{0}=$ standar minimal

$n=$ jumlah sampel

Pengujian hipotesis ini menggunakan uji t-tes satu pihak, yaitu uji pihak kanan dengan pasangan hipotesis

$\mathrm{H}_{0}: \mu<\mu_{0}$

$\mathrm{H}_{1}: \mu \geq \mu_{0}$

Kriteria pengujian didapat dari daftar distribusi student $\mathrm{t}$ dengan $\mathrm{dk}=$ (n-1) dan peluang (1- $\alpha$ ). Jadi kita tolak $\mathrm{H}_{0}$ jika $\mathrm{t} \geq \mathrm{t}_{1-\alpha}$ dan terima $\mathrm{H}_{0}$ jika $\mathrm{t}$ $\leq . \mathrm{t}_{1-\alpha}$.

\section{Analisis Deskriptif Hasil Belajar Matematika}

Berdasarkan data hasil belajar matematika skor maksimum yang dicapai oleh peserta didik yang diajar dengan metode tutor sebaya berbantuan modul pembelajaran matematika berbasis keterampilan literasi dalam pembelajaran matematika, yaitu 92 dari 100 skor yang mungkin dicapai dan skor terendah yang dicapai peserta didik adalah 69 dari skor 0 yang mungkin dicapai. Skor rata-rata 81,53 dengan standar deviasi 7,76.

Adapun kategori kemampuan peserta didik yang diajar dengan metode tutor sebaya berbantuan modul pembelajaran matematika berbasis keterampilan literasi sebagian besar berada pada kategori sedang yaitu sebanyak 6 orang atau sebanyak $40 \%$ dari jumlah keseluruhan peserta didik, sedangkan yang lain berada pada kategori tinggi dan sangat tinggi, untuk kategori tinggi sebanyak 5 orang atau sebanyak 33\% dari jumlah

\footnotetext{
${ }^{11}$ Sudjana, Metode Statistika (Bandung: PT. Tarsito, 2005).
} 
keseluruhan peserta didik dan untuk kategori sangat tinggi sebanyak 4 orang atau $27 \%$ dari jumlah keseluruhan peserta didik.

Jika dikaitkan dengan Kriteria Ketuntasan Minimum (KKM) yang ditetapkan oleh sekolah yakni 75. Berdasarkan hasil dari 15 orang peserta didik, 12 orang atau 80\% tuntas sedang sisanya 3 orang atau 20\% tidak tuntas. Hal ini menunjukkan bahwa sebagian besar hasil belajar peserta didik memenuhi kriteria ketuntasan minimal.

\section{Hasil Analisis Inferensial}

Sebelum dilakukan pengujian hipotesis dilakukan terlebih dahulu uji normalitas untuk mengetahui apakah data berdistribusi normal atau tidak.Berdasarkan hasil uji normalitas data menunjukkan nilai Kol-Smirnov sebesar 0,499 dengan Asymp. Sig yaitu sebesar 0,964 >0,05 sehingga dapat disimpulkan data berdistribusi normal.

Karena data berdistribusi normal selanjutnya dilakukan pengujian hipotesis dengan menggunakan uji-t satu pihak. Hasil belajar matematika peserta didik setelah diterapkan metode tutor sebaya berbantuan modul pembelajaran matematika berbasis keterampilan literasitelah mencapai standar minimal.

Hasil analisis data menunjukkan bahwa $t_{\text {hitung }}=40,676$ sedangkan untuk t tabel diperoleh dengan $\mathrm{df}=14$, sig 5\% (taraf nyata $\alpha=0,05)$, tabel $=1,76$, karena $t_{\text {hitung }}>t_{\text {tabel }}$ maka hipotesis Ho ditolak dan $\mathrm{H}_{1}$ diterima. Hal ini berarti bahwa Hasil belajar matematika peserta didik setelah diterapkan metode tutor sebaya berbantuan modul pembelajaran matematika berbasis keterampilan literasi telah mencapai standar minimal.

Berdasarkan analisis data dengan menggunakan analisis deskriptif dan analisis inferensial, analisis deskriptif manunjukkan bahwa hasil belajar matematika peserta didik kelas $\mathrm{XI}_{\mathrm{B}} \mathrm{MA}$ Ihya Ulumiddin yang diajar dengan menerapkan metode tutor sebaya berbantuan modul pembelajaran matematika berbasis keterampilan literasi memperoleh skor rata-rata 81,53 dari 100 skor total yang mungkin dicapai, dengan skor tertinggi yang dicapai adalah 92 dari 100 yang mungkin dicapai dan skor terendah yang dicapai peserta didik adalah 69 dari skor 0 yang mungkin dicapai.dan dengan standar deviasi 7,76.

Jika skor disesuaikan dengan standar minimal menunjukkan bahwa standar minimal yang dicapai yaitu 75 \% sehingga dapat dikemukakan bahwa peserta didik yang telah mencapai standar minimal sebanyak 12 peserta didik (80\%). 
Selanjutnya dari analisis inferensial pada pengujian hipotesis, hasil yang diperoleh adalah $\mathrm{H}_{0}$ ditolak dan $\mathrm{H}_{1}$ diterima, hal ini menunjukkan bahwa hasil belajar matematika peserta didik yang diajar dengan menerapkan metode tutor sebaya berbantuan modul pembelajaran matematika berbasis keterampilan literasi telah mencapai standar minimal yaitu $75 \%$.

Analisis deskriptif dan analisis inferensial tersebut memberikan indikasi bahwa peserta didik yang diajar dengan metode tutor sebaya berbantuan modul pembelajaran matematika berbasis keterampilan literasi berada di atas $75 \%$. Sehingga dapat dikemukakan bahwa peserta didik yang diajar dengan metode tutor sebaya berbantuan modul pembelajaran matematika berbasis keterampilan literasi pada umumnya telah mencapai standar minimal.

Jika dilihat dari hasil belajar yang dicapai peserta didik melalui metode tutor sebaya berbantuan modul pembelajaran matematika berbasis keterampilan literasi membuat peserta didik termotivasi dalam mengikuti materi pembelajaran dan peserta didik tidak merasa jenuh dalam mengikuti suatu mata pelajaran khususnya mata pelajaran matematika, karena peserta didik aktif dalam proses belajar mengajar. Hal ini dikarenakan peserta didik tidak merasa segan dan malu untuk bertanya kepada tutor yang ada pada tiap kelompok-kelompok kecil, sebab tutor mereka adalah teman sebaya mereka sendiri.

Metode tutor sebaya berbantuan modul pembelajaran matematika berbasis keterampilan literasi ini merupakan salah satu cara agar peserta didik lebih berani lagi untuk aktif dalam proses belajar mengajar terutama aktif bertanya tentang apa saja yang belum mereka pahami. Peserta didik tidak akan merasa malu untuk bertanya kepada tutornya tersebut yaitu kepada temannya sendiri, karena dengan teman sebaya tidak akan ada rasa enggan, rendah diri, canggung, dan sebagainya, sehingga diharapkan peserta didik yang kurang paham tidak segan-segan untuk mengungkapkan kesulitan-kesulitan yang dihadapinya. Selain itu bahasa teman sebaya lebih mudah dipahami sehingga akan lebih mempermudah peserta didik dalam proses pamahamannya.

Berdasarkan uraian tersebut dapat dikatakan bahwa hasil belajar matematika yang dicapai peserta didik setelah penerapan metode tutor sebaya berbantuan modul pembelajaran matematika berbasis keterampilan literasi memberikan indikasi bahwa peserta didik telah mencapai hasil belajar yang cenderung optimal. Hal ini sejalan dengan hasil penelitian Ruseno Arjanggi dan Titin Suprihatin yang menyatakan bahwa ada pengaruh 
yang positif metode pembelajaran tutor sebaya terhadap hasil belajar ${ }^{12}$. Pembelajaran aktif bias dilakukan tanpa harus melibatkan banyak tenaga pengajar, dengan mencoba memaksimalkan potensi yang ada salah satunya dengan dengan tutor sebaya.

\section{Penutup}

\section{Simpulan}

Kesimpulan dari penelitian ini, yaitu:

1. Hasil belajar matematika peserta didik setelah diterapkan metode tutor sebaya berbantuan modul pembelajaran matematika berbasis keterampilan literasi mencapai rata-rata 81,53.

2. Setelah metode tutor sebaya berbantuan modul pembelajaran matematika berbasis keterampilan literasi diterapkan dalam pembelajaran matematika pada kelas $\mathrm{XI}_{\mathrm{B}}$ MA Ihya Ulumiddin pada tahun ajaran 2016/2017 maka hasil belajar matematika peserta didik telah mencapai standar minimal.

3. Metode tutor sebaya berbantuan modul pembelajaran matematika berbasis keterampilan literasi merupakan salah satu metode pembelajaran yang dapat digunakan dalam mencapai hasil belajar matematika yang optimal.

\section{Saran}

1. Penggunaan metode tutor sebaya berbantuan modul pembelajaran matematika berbasis keterampilan literasi dengan pemanfaatan peserta didik yang pandai sebagai sumber belajar dapat dipertimbangkan sebagai salah satu variasi dalam pembelajaran matematika karena dalam penelitian ini terbukti bahwa peserta didik telah mencapai hasil belajar yang optimal.

2. Untuk penelitian selanjutnya, bagi peneliti yang ingin mengembangkan peneltian yang sama, hendaknya mencermati keterbatasan penelitian ini agar penelitian dapat lebih berkualitas.

12 Ruseno Arjanggi and Titin Suprihatin, "Metode Pembelajaran Tutor Teman Sebaya Meningkatkan Hasil Belajar Berdasar Regulasi-Diri," Hubs-Asia 10, no. 1 (November 4, 2011), http://hubsasia.ui.ac.id/old/index.php/hubsasia/article/view/666. 


\section{Daftar Pustaka}

Anita, Wahyudi, and Miliani. "Pengaruh Remedial Teaching Tutor Sebaya Dalam Mengatasi Kesulitan Belajar Siswa Pada Materi Hukum Newton Kelas X IPA SMA Negeri 1 Jongkong Kabupaten," 2017.

Arjanggi, Ruseno, and Titin Suprihatin. "Metode Pembelajaran Tutor Teman Sebaya Meningkatkan Hasil Belajar Berdasar Regulasi-Diri." Hubs-Asia 10, no. 1 (November 4, 2011). http://hubsasia.ui.ac.id/old/index.php/hubsasia/article/view/666.

Darmiatun. Menyusun Modul Bahan Ajar Untuk Persiapan Guru Dalam Mengajar. Yogyakarta: Gava Media, 2013.

Fathurrohman, Pupuh, and M. Sobry Sutikno. Strategi Belajar Mengajar Melalui Penanaman Konsep Umum dan Konsep Islami Edisi 1. Refika Aditama, 2011. https://openlibrary.telkomuniversity.ac.id/pustaka/21504/strategibelajar-mengajar-melalui-penanaman-konsep-umum-dan-konsepislami-edisi-1.html.

Fauzan, Muhammad, Noor Taufiq Saleh, and Ardhi Prabowo. "Penerapan Pembelajaran Model PBL Dengan Metode Tutor Sebaya Pada Materi Statistika Untuk Meningkatkan Ketuntasan Klasikal Siswa Kelas XII MIPA 1 SMAN 9 Semarang Tahun Pelajaran 2018/2019." PRISMA, Prosiding Seminar Nasional Matematika 2 (February 13, 2019): 403-9.

Hamalik, Oemar. Proses Belajar Mengajar. Jakarta: Bumi Aksara, 2017.

Indrayanti, Norma Y, and Endang Susilowati. Pengembangan Modul. Surakarta: Tim Pengabdian Kepada Masyarakat LPPM UNS, 2010.

OECD. "Pisa 2012 Assessment and Analytical Framework Mathematics, Reading, Science, Problem Solving and Financial Literacy." OECD Publishing, 2013. https://www.oecd.org/pisa/pisaproducts/PISA\%202012\%20framewo rk\%20e-book_final.pdf.

Sudjana. Metode Statistika. Bandung: PT. Tarsito, 2005.

Tim MKPBM Jurusan Pendidikan Matematika. "Strategi Pembelajaran Matematika Kontemporer." JICA Universitas Pendidikan Indonesia, 2001. http://file.upi.edu/Direktori/KD-

TASIKMALAYA/DINDIN_ABDUL_MUIZ_LIDINILLAH_\%28KDTASIKMALAYA\%29-197901132005011003/132313548\%20\%20dindin\%20abdul\%20muiz\%20lidinillah/Strategi\%20Pembelajara n\%20Matematika\%20\%28Lokakarya\%20Guru\%20SD\%20Kawalu\%29 .pdf.

Wadhani, Sri, and Rumiati. Instrumen Penilaian Hasil Belajar Matematika SMP Belajar Dari PISA Dan TIMSS. Yogyakarta: PPPPTK-Kemendikbud, 2011.

Winkel. Psikologi Pengajaran. Yogyakarta: Media Abadi, 2009. 